Acta vet. scand. $1974,15,244-255$.

From the Department of Microbiology and Microbial Ecology, and the Department of Animal Nutrition,

Royal Veterinary and Agricultural University, Copenhagen, Denmark.

\title{
THE MICROFLORA AND CONCENTRATIONS OF VOLATILE FATTY ACIDS IN THE RUMEN OF CATTLE FED ON SINGLE COMPONENT RATIONS*
}

\author{
By \\ Jens Wolstrup, Vagn Jensen and Kurt Jensen
}

\begin{abstract}
WOLSTRUP, JENS, VAGN JENSEN and KURT JENSEN: The microflora and concentrations of volatile fatty acids in the rumen of cattle fed on single component rations. Acta vet. scand. 1974, 15, 244-255. - The composition of the rumen microflora and the volatile fatty acids were examined in cattle free-grazing on grass or stall-fed on hay, grass pellets, oats or dried beet pulp with molasses. Total and viable counts of anaerobic bacteria were highest on the grass feeding, but viable counts as a percentage of total counts were highest when oats or beet pulp with molasses were fed. Counts of cellulolytic bacteria were lowest on these latter 2 diets, and highest on grass or grass pellet diets. Studies of the anaerobic flora showed that the composition in animals fed on grass pellets resembled more that found in animals free-grazing on grass than in those fed on hay. Counts of aerotolerant bacteria were only a small percentage of the total count, but were highest on the hay diet. On this latter diet and on grass-feeding the streptococci (identified as Streptococcus bovis) were predominant, but contrary to expectation, streptococci were found only in small numbers on the oats diet, where coryneform rods were the major type present. Although a period of $4-6$ weeks was allowed for the animals to adapt to the feeds, the 2 periods of feeding on oats and dried beet pulp with molasses markedly affected the composition of the rumen flora in the subsequent periods of feeding grass pellets and hay. Rumen volatile fatty acid analysis showed a propionogenic effect of oats and the highest percentage of butyric acid when beet pulp with molasses was fed. The expected propionogenic effect of grass pellets was not observed.
\end{abstract}

rumen bacteria; VFA; single component rations.

- The work was financially supported by the Danish Agricultural and Veterinary Research Council. 
During the last decade hay has been partly replaced by grass pellets as fodder component of ruminant feeds. Since grass for pellets is harvested at an earlier stage of growth than for hay, and since the grass is ground prior to pelleting, it is feasible that the rumen microflora responds differently to the 2 types of feed. The composition of the rumen microflora in cows fed on hay has been extensively studied (Maki \& Foster 1957, Caldwell \& Bryant 1966, Elias 1971, Latham et al. 1971). However, only Thorley et al. (1968) have examined the differences which accompany the feeding of grass pellets or hay. The possible relationships between the feed, the composition of the bacterial flora and the rumen volatile fatty acids have been investigated by several workers (Warners 1962, Eadie et al. 1970, Latham et al.), but are still far from being finally settled.

The aim of the present study was to contribute to the further elucidation of the rumen microflora and the volatile fatty acids associated with feeding on roughage (hay, dried grass or grass pellets) or rations higher in easily digestible carbohydrate (oats or dried pulp with molasses).

\section{MATERIALS AND METHODS}

Animals and feeds

All animals had been fitted with Balch cannulae and grazed on grass prior to the experiments. The experimental plan and feed compositions are shown in Table 1. Two dry cows were used in periods I and II and 2 heifers in periods III to VIII inclusive. The rations, except in period II, were fed in equal portions at 8 a. m. and $4 \mathrm{p} . \mathrm{m}$. and were supplemented with vitamins and minerals. Water was available at all times. Every experimental period was of 2 months' duration, and the 2 final periods on grass pellets and hay were included to see if any long-term changes in the microflora occurred.

\section{Sampling}

One or 2 samples of rumen fluid in amounts of $250 \mathrm{ml}$ were collected into preheated thermos flasks from each animal $4-6$ weeks after the commencement of each feeding period. The samples were taken $4 \mathrm{hrs}$. after the morning feeding except from the free-grazing cows which were sampled in the afternoon.

\section{Bacterial counts}

Total counts were made on suitable dilutions of rumen fluid in a $0.02 \mathrm{~mm}$ deep Thoma counting chamber.

Viable counts of anaerobic bacteria were made using the roll-tube technique (Hungate 1950). The diluent and medium were non-selective and were partly based on the multisugar medium I of Kurihara 
et al. (1968). Each $100 \mathrm{ml}$ of the medium contained the following: $30 \mathrm{ml}$ rumen fluid, $15 \mathrm{ml}$ mineral solution $\mathrm{A}, 15 \mathrm{ml}$ mineral solution $\mathrm{B}, 30 \mathrm{ml}$ distilled water, $0.25 \mathrm{~g}$ yeast extract, $1.0 \mathrm{~g}$ Bacto casitone, $1.0 \mathrm{~g}$ sodium lactate, $1.0 \mathrm{ml} \mathrm{RC}$ solution, $0.1 \mathrm{ml}$ resazurin solution $(0.1 \% \mathrm{w} / \mathrm{v})$ and $2.2 \mathrm{~g}$ agar. The $\mathrm{RC}$ solution was composed as follows: $5 \mathrm{~g} \mathrm{NaHCO}_{3}, 0.25$ g cysteine $\mathrm{HCL}, 0.25 \mathrm{~g} \mathrm{Na}_{2} \mathrm{~S} .9 \mathrm{H}_{2} \mathrm{O}, 3$ g cellobiose, $3 \mathrm{~g}$ glucose, $3 \mathrm{~g}$ maltose and distilled water ad $100 \mathrm{ml}$. The rumen fluid was taken from a cow fed on grass pellets, concentrate and straw. It was centrifuged at $30,000 \times \mathrm{g}$ for $10 \mathrm{~min}$. and then filtered through a Seitz EK filter.

The $10^{-1}$ dilution of each rumen sample was prepared in a solution which differed from the medium in that it only contained $15 \mathrm{ml}$ rumen fluid per $100 \mathrm{ml}$ and did not contain Bacto casitone, yeast extract, sodium lactate, carbohydrates or agar. The solutions were mixed in a Waring blender for $2 \mathrm{~min}$. with anaerobiosis being maintained by a vigorous stream of carbon dioxide. Further 10-fold dilutions were prepared from this mixture and the diluent.

The diluent and culture medium for counting aerotolerant bacteria were the same as described above except that the reducing agents, redox indicator and bicarbonate were omitted. Dilutions were performed in air and counts were made on aerobically incubated Petri dishes.

Cellulolytic bacteria were counted by the MPN method of Mann (1968) but with the medium modified by the omission of cellobiose.

\section{Morphological classification}

The anaerobic bacteria were classified by subculturing the colonies in a liquid medium which was of the same composition as the non-selective medium. The subcultures were incubated for $48 \mathrm{hrs}$. at $38^{\circ} \mathrm{C}$ and then, after microscopic examination, classified in the following groups:

Group 1: Gram-positive to Gram-variable cocci (e.g. Ruminococcus). Group 2: Gram-negative cocci (e.g. Megasphaera elsdenii).

Group 3: Gram-positive to Gram-variable rods.

Group 4: Gram-positive, coccoid rods (e.g. Lactobacillus).

Group 5: Gram-positive, spore-forming rods (e.g. Clostridium).

Group 6: Gram-negative, coccoid to long rods (e.g. Bacteroides).

Group 7: Gram-negative, crescent-shaped rods (probably Selenomonas ruminantium).

Group 8: Gram-positive to Gram-variable vibrios.

Group 9: Gram-negative vibrios (e.g. Butyrivibrio).

Group 10: Gram-negative spirilla (e.g. Treponema).

Isolates for the classification of aerotolerant bacteria were made after colony counting by subculturing on to the counting medium and classified according to the following characteristics:

Group 1: Gram-positive cocci in chains (Streptococcus spp.).

Group 2: Other cocci, generally Gram-positive (Staphylococcus, Micrococcus, Sarcina, etc.). 
Group 3: Spore-forming rods, Gram-positive to Gram-negative (Bacillus spp.).

Group 4: Non-spore-forming, regular rods, Gram-positive, Gram-variable or Gram-negative.

Group 5: Coryneform rods, Gram-positive or Gram-variable.

Group 6: Bacterial types not belonging to any of the above mentioned groups (e.g. Nocardia, Streptomyces).

Thirty-four isolates of aerotolerant streptococci were selected at random and tested in detail. They were all identified on the basis of biochemical tests as Streptococcus bovis.

\section{Volatile fatty acids (VFA)}

The concentration and molar composition of the VFA's were determined by gas-solid adsorption chromatography of rumen fluid after the addition of phosphoric and isocaproic acid (Jensen 1973).

\section{RESULTS AND DISCUSSION}

In spite of the differences in the composition of the 2 lots of hay and of grass pellets which were used in periods I, III, VI and VII (Table 1), it seems likely that the large differences in total counts and counts of anaerobic, aerotolerant and cellulolytic bacteria (Table 2) between the first 2 and the last 2 periods were due to the influence of the long intermediate period of feeding non-grass-based diets, as the counts in the last 2 periods were in general similar to those in the intermediate period. However, there is evidence of a return to the original hay flora after 4 to 6 weeks of hay feeding in period VII, especially in the case of the cellulolytic bacteria. It would seem best on the whole to regard the periods I and III as more typical of hay or grass pellet feeding. But the results did show that a very long period of adaptation to a fairly drastic change in diet is probably necessary, before the rumen flora can be considered stabilized, particularly when the change involves an increase in the population of bacteria. The latter effect was observed after period V. The 4-6 weeks used here was similar to that used by other workers (e. g. Latham et al. 1971) and was longer than in many reported feeding trials.

The anaerobic viable count expressed as a percentage of the total count was of the same order in each of the periods I, II, III, VI and VII. This was probably a function of the available nutrients in the rumen fluid, and so was not expected to be influenced by the previous dietary regime. The higher viable per- 
T a ble 1. Rations and feed composition.

\begin{tabular}{rlccccccc}
\hline $\begin{array}{c}\text { Experi- } \\
\text { mental } \\
\text { period }\end{array}$ & \multicolumn{1}{c}{ Feed } & $\begin{array}{c}\mathrm{kg} \\
\text { feed } \\
\text { per day }\end{array}$ & $\begin{array}{c}\text { Dry } \\
\text { matter } \\
\%\end{array}$ & $\begin{array}{c}\text { crude } \\
\text { protein }\end{array}$ & $\begin{array}{c}\text { crude } \\
\text { fat }\end{array}$ & $\begin{array}{c}\text { crude } \\
\text { fibre }\end{array}$ & $\begin{array}{c}\text { N-free } \\
\text { extracts }\end{array}$ & $\begin{array}{c}\text { crude } \\
\text { ash }\end{array}$ \\
\hline I & hay & 10 & 90.9 & 13.6 & 3.0 & 30.3 & 46.4 & 6.8 \\
II & grass (grazing) & ad libitum & - & - & - & - & - & - \\
III & grass pellets & 6 & 91.5 & 13.8 & 3.7 & 24.4 & 47.6 & 11.1 \\
IV & oats (rolled) & 4 & 94.5 & 15.7 & 5.2 & 8.6 & 67.6 & 2.9 \\
V & dried beet pulp & & & & & & & \\
& with molasses & 4 & 91.7 & 13.6 & 0.6 & 11.9 & 66.6 & 7.3 \\
VI & grass pellets & 6 & 91.9 & 15.3 & 2.7 & 31.0 & 41.9 & 9.1 \\
VII & hay & 8 & 93.0 & 16.1 & 3.2 & 30.3 & 43.9 & 6.5 \\
\hline
\end{tabular}

centage in the rumen flora of the animals on the high-carbohydrate rations in periods IV and $\mathrm{V}$ agreed with the results of Bryant \& Burkey (1953), Maki \& Foster (1957) and Whitelaw et al. (1972).

The total counts, anaerobic viable counts and counts of cellulolytic bacteria (Table 2) were of the same order as those found by other workers using rations similar to those used here (e. g. Caldwell \& Bryant 1966, Oltjen et al. 1966 and Bryant \& Robinson 1968). The highest viable count of anaerobes was found in period IV when rolled oats were fed. This effect on the viable count of anaerobes by replacing hay with concentrates has also been observed by Bryant \& Burkey and by Maki \& Foster but not by Latham et al.

Both the viable count of cellulolytic bacteria and the percentages of cellulolytic bacteria in anaerobic colony counts decreased after periods I, II and III when grass and grass products were fed, to the low values in periods IV and V when the diets contained larger amounts of non-cellulose carbohydrates. The diet fed in period $\mathrm{V}$ contained a higher proportion of crude fibre than in period IV (Table 1), and the cellulolytic count was correspondingly higher (Table 2). Bryant \& Burkey and Latham et al. also observed decreases in the cellulolytic bacteria counts when high starch rations were fed. The highest counts of cellulolytic bacteria corresponded with the highest proportions of Gramnegative vibrios (morphologically Butyrivibrio) in the flora (Table 3 ). The percentage of these vibrios was low in period VI when total counts and counts of cellulolytic bacteria were below those expected, but was similar in period I to that in period VII 


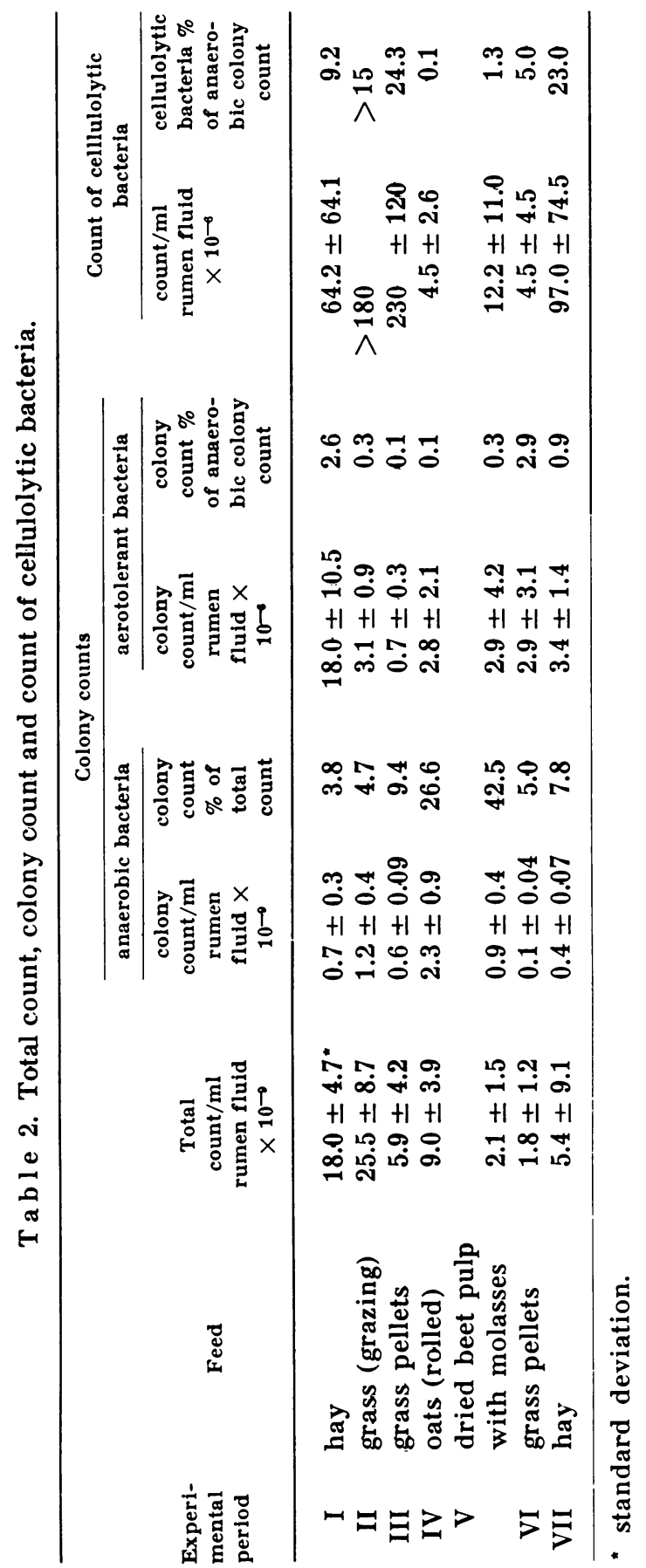




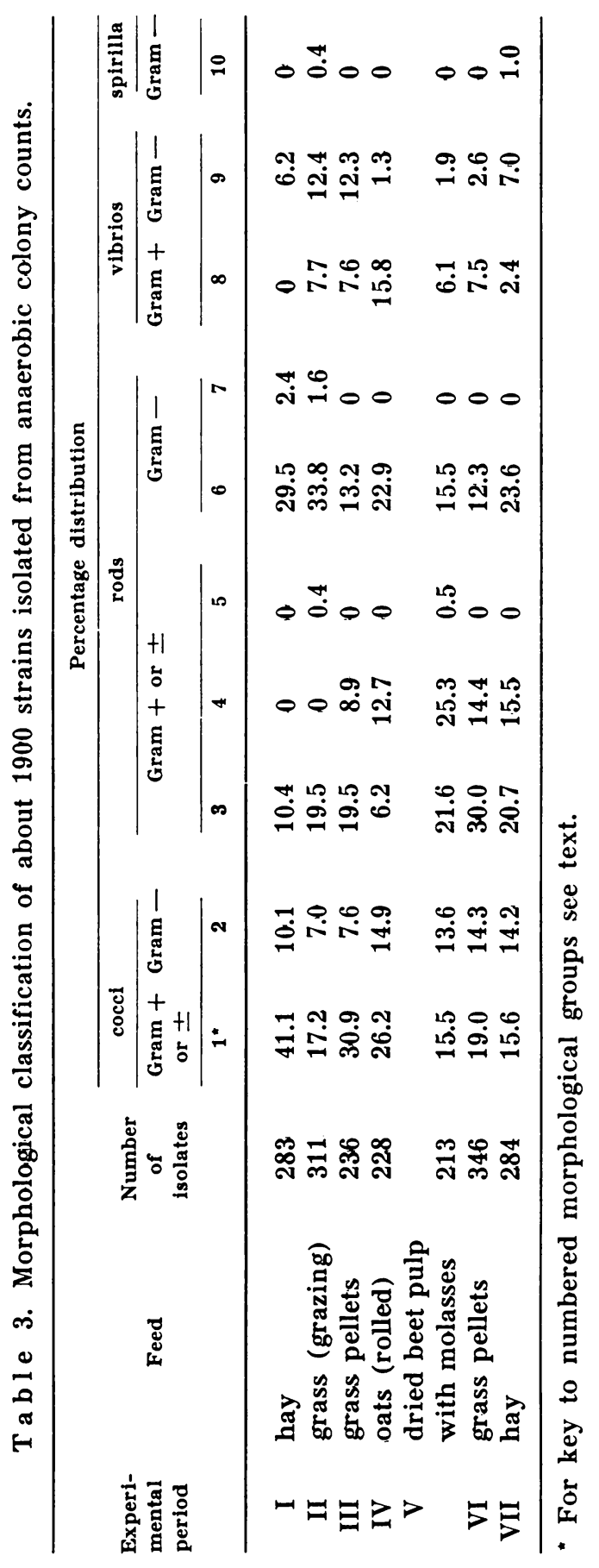


when the rumen flora appeared to be recovering from the long period on feeds without grass. It is also apparent from Table 3 that the influence of the periods IV and V extended to periods VI and VII not only in numbers of bacteria, but also in types. Latham et al. found higher numbers of Butyrivibrio in cows fed on hay than when fed on cereal plus hay rations, and Butyrivibrio has been found to be the most common cellulolytic bacterium in the rumen at times (Gouws \& Kistner 1965), although the more actively cellulolytic ruminococci sometimes appear to be present in greater numbers (Bryant \& Burkey 1953, Kistner et al. 1962). The ruminococci were grouped in the Gram-positive to Gramvariable cocci in Table 3 , and there was no obvious relationship between these and the cellulolytic bacteria. Large numbers of selenomonads have sometimes been found in animals on high grain rations, but the effect cannot be consistently demonstrated. Thus, whereas Latham et al. found an increase in the percentage of selenomonads when cows were changed from hay to cereal rations, the opposite effect was observed in our experiment. The Gram-negative cocci, morphologically similar to Megasphaera elsdenii, increased when the high carbohydrate rations were fed (Table 3, group 2) and this was expected. Group 4 (Lactobacillus) isolates also increased in number during periods IV and V. The relative proportions of the different bacterial groups in the rumen fluid from animals fed on grass pellets resembled those from grass fed animals more than those from animals fed on hay. The same effect has previously been reported by Thorley et al. (1968).

The aerotolerant bacteria (including aerobes, facultatively anaerobes and aerotolerant anaerobes) formed only a small fraction of the total viable bacteria, and occurred in numbers of about $10^{6}$ per $\mathrm{ml}$ rumen content (Table 2 ). This value was similar to earlier estimates of the numbers of aerotolerant bacteria in adult cattle although rather higher values have been reported. The variation in the numbers of these bacteria is however to be expected since, with the exception of Streptococcus bovis which appears to be a true rumen inhabitant, most of the facultative or aerobic bacteria cultured from the rumen are probably "passengers" introduced with the feed (Gutierrez 1953, A ppleby 1955). The feeding on oats ration was expected to result in high counts of the amylolytic Streptococcus bovis, but this was not found (Table 4). There appeared to be an inverse relationship between 
T a b l e 4. Morphological classification of about 2500 strains isolated from aerobic colony counts.

\begin{tabular}{|c|c|c|c|c|c|c|c|c|c|}
\hline \multirow{3}{*}{$\begin{array}{l}\text { Experi- } \\
\text { mental } \\
\text { period }\end{array}$} & \multirow{3}{*}{ Feed } & \multirow{3}{*}{$\begin{array}{c}\text { Number } \\
\text { of } \\
\text { isolates }\end{array}$} & \multicolumn{7}{|c|}{ Percentage distribution } \\
\hline & & & \multirow{2}{*}{$\begin{array}{c}\text { strepto- } \\
\text { cocci } \\
1^{*}\end{array}$} & \multirow{2}{*}{$\begin{array}{c}\text { cocci, } \\
\text { not in } \\
\text { chains } \\
2\end{array}$} & \multirow{2}{*}{$\begin{array}{c}\text { spore- } \\
\text { forming } \\
\text { rods } \\
3\end{array}$} & \multicolumn{2}{|c|}{ non-sporeforming rods } & \multirow{2}{*}{$\begin{array}{c}\text { others } \\
6\end{array}$} & \multirow{2}{*}{$\begin{array}{l}\text { no growth } \\
\text { after } \\
\text { transfer }\end{array}$} \\
\hline & & & & & & $\underset{4}{\text { regular }}$ & $\begin{array}{c}\text { coryneform } \\
5\end{array}$ & & \\
\hline I & hay & 478 & 68.4 & 1.9 & 9.2 & 2.7 & 16.1 & 0.4 & 1.3 \\
\hline II & grass (grazing) & 400 & 69.2 & 3.4 & 0.3 & 12.2 & 12.5 & 0 & 2.0 \\
\hline III & grass pellets & 100 & 6.0 & 7.0 & 1.0 & 21.0 & 63.0 & 0 & 2.0 \\
\hline IV & oats (rolled) & 333 & 0.9 & 0 & 4.8 & 17.7 & 69.7 & 3.3 & 3.6 \\
\hline \multirow[t]{2}{*}{ V } & dried beet pulp & & & & & & & & \\
\hline & with molasses & 400 & 17.7 & 3.8 & 0.5 & 19.2 & 47.5 & 1.8 & 9.5 \\
\hline VI & grass pellets & 400 & 2.0 & 10.8 & 2.3 & 17.7 & 59.5 & 4.7 & 3.0 \\
\hline VII & hay & 400 & 17.7 & 19.7 & 5.3 & 10.5 & 39.0 & 6.0 & 1.8 \\
\hline
\end{tabular}

* For key to numbered morphological groups see text.

the numbers of Streptococcus bovis and of the coryneform rods, while variations in other types of aerotolerant bacteria were smaller and probably fortuitous.

Our results of the VFA analysis agreed with those of Latham et al. (1971) in that there was no relationship between the VFA pattern and the number and bacterial types isolated. The oats ration resulted in the highest propionic acid concentration while the highest proportion of butyric acid was found on the beet pulp plus molasses ration (Table 5 ). The latter result confirmed the earlier findings of Elias (1971) who found molar percentages of butyric acid ranging from 15 to 26 in calves fed on various molasses-based diets. The grass-based diets gave essentially the same mixture of VFA but with a lower proportion of butyric acid. An expected propionogenic effect of grass pellets compared with the effect of feeding grass and hay was not demonstrated. This was in contrast to the findings of Balch (1958) who found that feeding ground hay resulted in a higher concentration of propionic acid in the rumen fluid than when long hay was fed.

\section{ACKNOWLEDGEMENTS}

The authors wish to express their sincere appreciation to Dr. P. N. Hobson for valuable discussions and for reviewing the manuscript. The skillful and efficient technical assistance of Lise Lotte Berring, Lisbeth Lülloff, Ulla Hartmann Petersen and Dorthe Rasmussen is also appreciated. 


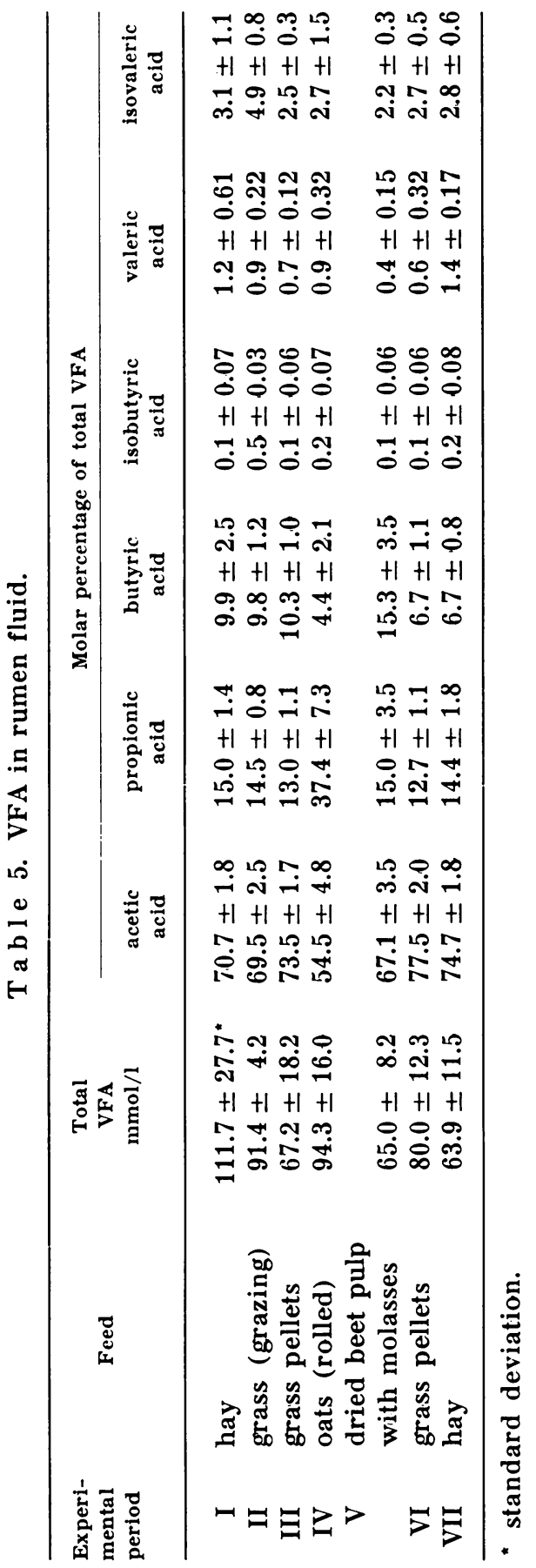




\section{REFERENCES}

Appleby, J. C.: The isolation and classification of proteolytic bacteria from the rumen of the sheep. J. gen. Microbiol. 1955, 12, 526533.

Balch, D. A.: An estimate of the weights of volatile fatty acids produced in the rumen of lactating cows on a diet of hay and concentrates. Brit. J. Nutr. 1958, 12, 18-24.

Bryant, M.P.\&L.D. Burkey: Cultural method and some characteristics of some of the more numerous groups of bacteria in the bovine rumen. Numbers and some predominant groups of bacteria in the rumen of cows fed different rations. J. Dairy Sci. 1953, 36, $205-224$.

Bryant, M.P.\& I. M. Robinson: Effects of diet, time after feeding and position sampled on numbers of viable bacteria in the bovine rumen. J. Dairy Sci. 1968, 51, 1950-1955.

Caldwell, D. R. \& M. P. Bryant: Medium without rumen fluid for nonselective enumeration and isolation of rumen bacteria. Appl. Microbiol. 1966, 14, 794-801.

Eadie, J. M., J. Hyldgaard-Jensen, S. O. Mann, A. S. Reid \& F. C. Whitelaw: Observations on the microbiology and biochemistry of the rumen in cattle given different quantities of a pelleted barley ration. Brit. J. Nutr. 1970, 24, 157-177.

Elias, A.: Personal communication, 1971.

Gouws, L. \& L. Kistner: Bacteria in the ovine rumen. IV. Effect of change of diet on the predominant type of cellulosedigesting bacteria. J. agric. Sci. 1965, 64, 51-57.

Gutierrez, J.: Numbers and characteristic of lactate utilizing organisms in the rumen of cattle. J. Bact. 1953, 66, 123-128.

Hungate, R. E.: The anaerobic mesophilic cellulolytic bacteria. Bact. Rev. 1950, 1/4, 1-49.

Jensen, $K .:$ Gas-solid adsorption chromatographic determination of short-chain fatty acids in rumen fluid. Acta vet. scand. 1973, 14, 335-337.

Kistner, A., L. Gouws \& F. M. Gilchrist: Bacteria of the ovine rumen. II. The functional groups fermenting carbohydrates and lactate on a diet of lucerne (Medicago sativa) hay. J. agric. Sci. 1962, $59,85-91$.

Kurihara, Y., J. M. Eadie, P. N. Hobson \& S. O. Mann: Relationship between bacteria and ciliate protozoa in the sheep rumen. $J$. gen. Microbiol. 1968, 51, 267-288.

Latham, M. J., M. E. Sharpe \& J.D. Sutton: The microbial flora of the rumen of cows fed hay and high cereal rations and its relationship to the fermentation. J. appl. Bact. 1971, 34, 425-434.

Maki, L. R. \& E. M. Foster: Effect of roughage in the bovine ration on types of bacteria in the rumen. J. Dairy Sci. 1957, 40, 905-913.

Mann, S. O.: An improved method for determining cellulolytic activity in anaerobic bacteria. J. appl. Bact. 1968, 31, 241-244. 
Oltjen, R. R., J. Gutierrez, R. P. Lehmann \& R. E. Davis: Rumen chemical and microbial characteristics of steers fed a purified and natural diet. J. Animal Sci. 1966, 25, 521-525.

Perry, K. D., M. K. Wilson, L. G. M. Newland \& C. A. E. Briggs: The normal flora of the bovine rumen. III. Quantitative and qualitative studies of rumen streptococci. J. appl. Bact. 1955, 18, $436-442$.

Thorley, C. M., M. E. Sharpe \& M. P. Bryant: Modification of the rumen bacterial flora by feeding cattle ground and pelleted roughage as determined with and without rumen fluid. J. Dairy Sci. 1968, $51,1811-1816$.

Warner, A. C. I.: Some factors influencing the rumen microbial population. J. gen. Microbiol. 1962, 28, $129-146$.

Whitelaw, F. G., J. M. Eadie, S. O. Mann \& R. S. Reid: Some effects of rumen ciliate protozoa in cattle given restricted amounts of a barley diet. Brit. J. Nutr. 1972, 27, 425-437.

\section{SAMMENDRAG}

Bakteriefloraen og koncentrationen af flygtige fedtsyrer $i$ vommen hos køer fodret med forskellige fodermidler.

Sammensætning af vommens bakterieflora og indhold af flygtige fedtsyrer unders $\emptyset$ gtes hos køer fodret udelukkende med græs, græspiller, $h \emptyset$, havre eller snitfoder. Totaltal og kolonital af anaerobe bakterier var højest hos græsfodrede køer, medens kolonital udtrykt som procent af totaltal var størst i perioderne med havre og snitfoder. Antallet af cellulolytiske bakterier var størst ved fodring med træstofrige fodermidler. Aerotolerante bakterier, som kun udgjorde en lille procentdel af det totale bakterietal, var højest hos høfodrede køer. Ved fodring med h $\phi$ og græs var streptokokker (identificeret som Streptococcus bovis) dominerende, hvorimod der ved fodring med havre, hvor coryneforme stave dominerede, fandtes et uventet lavt antal streptokokker. Sk $\varnothing$ nt overgangsperioderne varede 4-6 uger, påvirkede havre og snitfoder bakteriefloraens sammensætning i de efterfølgende perioder med græspiller og $h \emptyset$. Den molære fordeling af flygtige fedtsyrer viste den højeste procent eddikesyre ved fodring med græsmarksprodukter. En propionogen effekt af fodring med græspiller kunne, i modsætning til fodring med havre, ikke påvises. Den største molprocent af smørsyre fandtes ved fodring med snitfoder.

(Received December 11, 1973).

Reprints may be requested from: Jens Wolstrup, Department of Microbiology and Microbial Ecology, Royal Veterinary and Agricultural University, Rolighedsvej 21, DK-1958 Copenhagen V, Denmark. 